\title{
Investigation of Site Characterization in the Akdeniz Region by Using Seismic Refraction and Surface Wave Methods
}

\author{
Cengiz Kurtuluş* \\ Department of Geophysics, \\ Kocaeli University, Kocaeli, Turkey \\ Hamdullah Livaoğlu \\ Department of Geophysics, \\ Kocaeli University, Kocaeli, Turkey
}

\author{
Fadime Sertçelik \\ Department of Geophysics, \\ Kocaeli University, Kocaeli, Turkey \\ İbrahim Sertçelik \\ Department of Geophysics, \\ Kocaeli University, Kocaeli, Turkey
}

\author{
Sena İblikçi \\ Department of Geophysics, \\ Kocaeli University, Kocaeli, Turkey
}

\begin{abstract}
Multichannel Analysis of Surface Waves (MASW), Refraction Microtremor (ReMi), and Microtremor measurements was performed to predict site characterization at 65 strong-motion stations of AFAD (Disaster and Emergency Management Presidency) in the Akdeniz region in Turkey. Reliable field response information is required to investigate the region's impacts and assess the risk of the area. The soil conditions of the Akdeniz region are specified from MASW, ReMi, and Microtremor studies of AFAD's strong motion stations in this area. HVSR technique was conducted to determine dominant frequency values at different amplification levels. The Akdeniz region was classified according to Vs 30 based NEHRP Provisions [1], Eurocode-8 [2] and TBDY-2018 [3] and Rodrigez-Marek [4]. According to the [1], one station is classified as class A, 7 stations as B and 38 stations as $\mathrm{C}$ and 19 stations to be class D. According to [2], 6 stations correspond to class A, 39 stations B, and 20 stations D. The soil classes in the NEHRP system correspond to that of TBDY-2018 [3]. According to [4], 8 stations are classified as A, 17 stations B, 8 stations C-1, 13 stations C-2, 5 stations C-3,11 stations D-1, 1station D-2, 1 station D-3, 1 station E and 1 station is undistinguished. The predominant period of the region ranges from 0.07 to $1.47 \mathrm{~s}$, and the dominant magnification values vary between 0.79 and 8.5 .
\end{abstract}

Keywords: MASW, ReMi, microtremor measurements, Akdeniz region, Turkey

Received: 17 July 2018; Accepted: 18 September 2018; Published: 14 November 2018

\section{INTRODUCTION}

The Akdeniz (Mediterranean) region is located in a seismically active region in the southern part of Turkey. It constitutes about $15 \%$ of the total area of Turkey with a surface area of approximately $120,000 \mathrm{~km}^{2}$. The tectonic activity of the region shows a complex tectonic behavior under the influence of the faults of the Dead Sea, Eastern Anatolia and Cyprus [5]. In the last century (BC 37-2015), the ten largest destructive earthquakes in this area have shown that local site conditions have a major impact on the ground shaking. It has been reported that the tsunamis occurring in 1822 and 1872 earthquakes in Hatay lead to the death of 20 thousand people [6]. Microtremor survey of the various regions in Turkey, earthquake monitoring, a surface wave of research and several field effect study about the drilling data have been conducted [7, 8,

\footnotetext{
${ }^{*}$ Correspondence concerning this article should be addressed to Cengiz Kurtuluş, Department of Geophysics, Kocaeli University, Kocaeli, Turkey. E-mail: cengizk52@gmail.com

(c) 2018 The Author(s). Published by KKG Publications. This is an Open Access article distributed under a Creative Commons AttributionNonCommercial-NoDerivatives 4.0 International License.
} 
$9,10,11,12,13,14,15,16,17,18,19,20,21,22,23]$. [13] have used (H/V) spectral ratios to predict the strong motion site condition of Turkey. [15] and [24] applied geophysical and geotechnical studies in order to determine the field classification of Turkish strong movement areas. [25] analyzed the microtremor data for Antakya and suggested the initial micro-zonation map proposed for Antakya province based on the dominant periods ranging from 0.2 to $0.8 \mathrm{sec}$ and the shear wave velocities of the sediments covering the region. [26] examined the relationship between ground conditions and earthquake effect in Antakya. [27] investigated the seismicity of the region between Adana and Antakya-Kahramanmaras with $\mathrm{b}$ and risk analysis. [28] attempted to investigate the local site effects of MATNet, which consists of 55 uniaxial force balance accelerometers, and tried to record explosions that could be established near Hatay-K.Maras sites and evaluate them as part of an early warning and pre-damage estimate system. [29, 30] conducted microtremor array research on shallow $S$ wavelength velocity profiles in 41 sites in the Akdeniz region. In this study, seismic refraction, MASW, refraction microtremor (ReMi) and microtremor studies were carried out to investigate the distribution of S-wave velocity in shallow soils at 65 strong motion stations in Akdeniz region (Figure 1).

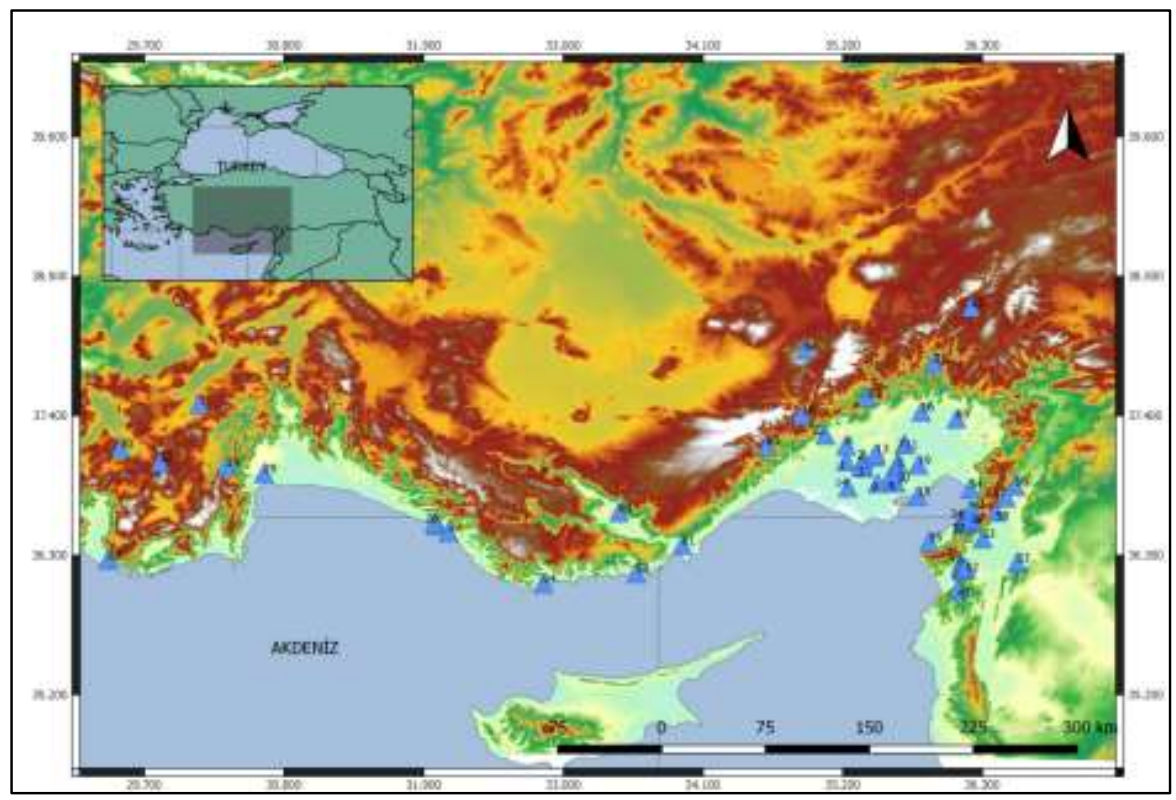

Fig. 1. Location of the study area. Triangles indicate the measuring stations

\section{GEOLOGY AND TECTONICS OF THE REGION}

The Miocene aged Netritic limestones are generally found in the Hatay region. Miocene aged carbonate and clastics are formed in the east of the region. Ordovician aged carbonates, Jura Neritic limestone, low-middle Cambrian quartz, Quaternary limestone are located in the central coastal areas. The Amanos Mountains and the Kzldag ophiolite massif at the south end of the Eastern Taurus Mountains also have an important place in the geology of the region (Figure 2). Pleistocene undifferentiated clastic are generally located in Adana and Hatay regions. Most of the mountains in the Mediterranean region constitute the western and central Taurus. Amanos Mountains and Samandag are among the important mountains in the east of the region. The Mediterranean region and its surrounding seismicity were formed as a result of the African and Arabian plates moving northwardly according to Eurasia. The African plate has been moving northward at about $10 \mathrm{~mm}$ per year in relation to Eurasia [31, 32]. Deep structures in the region, generally E-Woriented slope-displacement normal faults, north-southoriented strike-slip faulting, and west of the study area again consists of graben-horst block systems developing this tectonic result. 

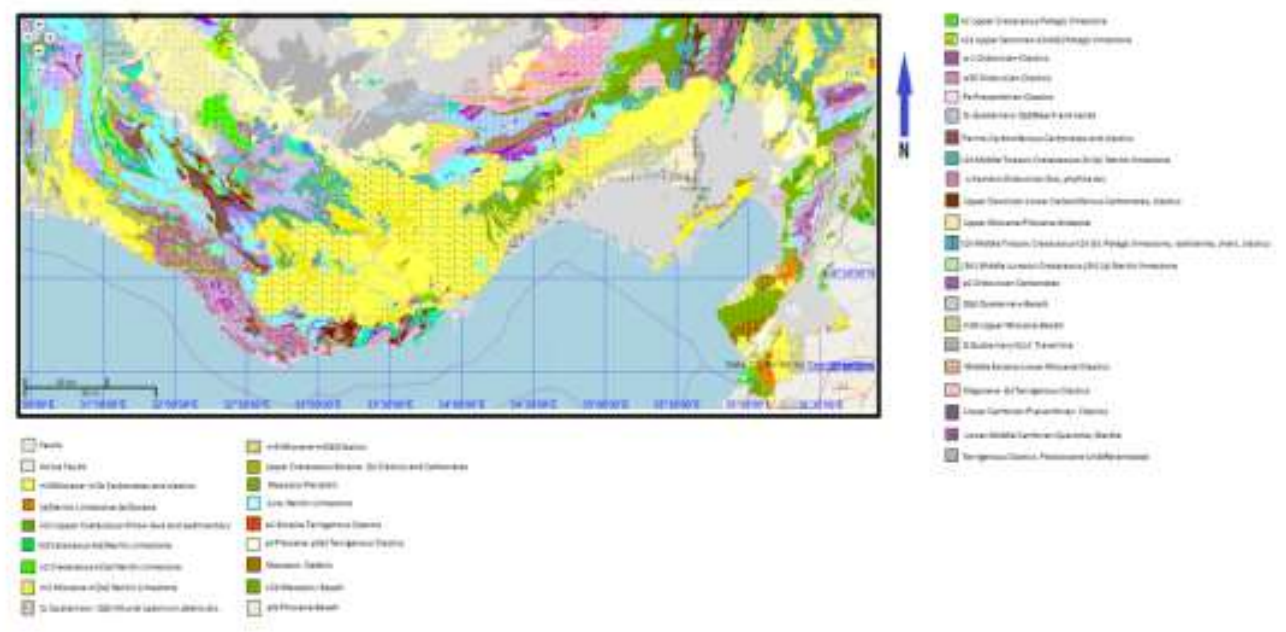

Fig. 2. Geological map of Akdeniz region

\section{DATA ACQUISITION AND ANALYSIS}

Seismic refraction, MASW, REMI, and microtremor data were collected at AFAD's 65 strong motion stations in Akdeniz region, southern Turkey.
Seismic refraction data were recorded for $2 \mathrm{sec}$ with a sampling rate of $1 \mathrm{msec}$ using a 50kg weight dropper energy source $484.5 \mathrm{~Hz}$ P-wave geophones were fixed at $2 \mathrm{~m}$ geophone intervals in line (Figure 3 ).

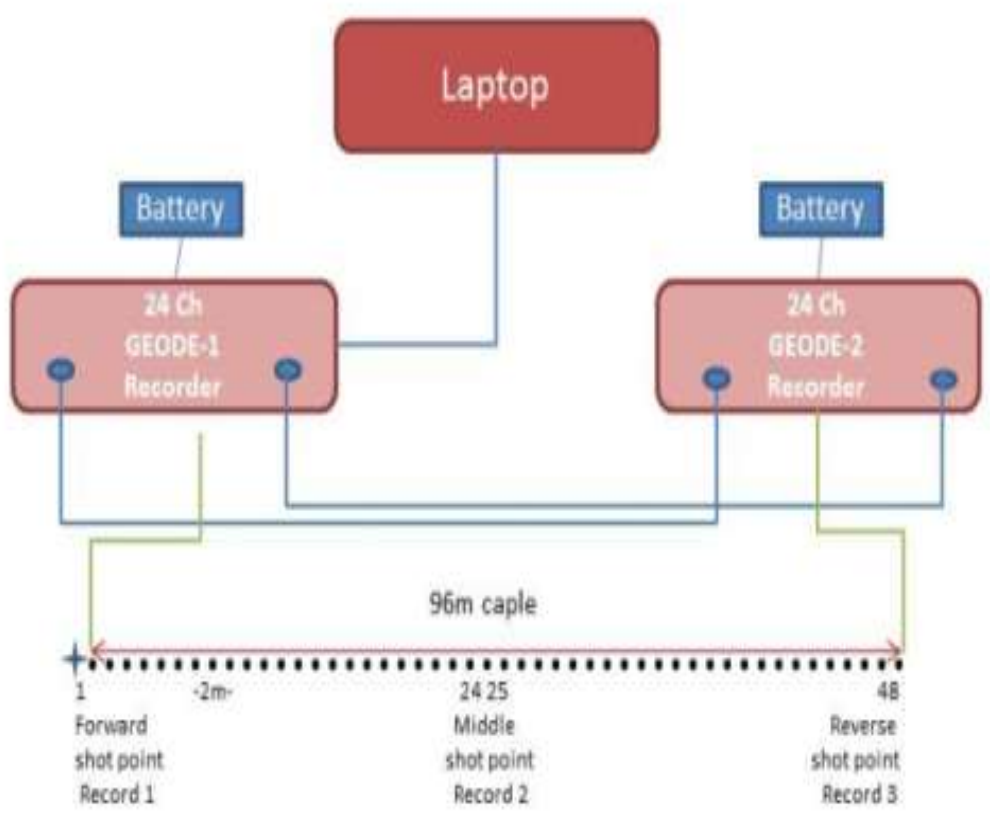

Fig. 3. Schematic of MASW data acquisition with a 48-channel linear receiving array

The shot records at each side were used in the analysis of the surface waves (MASW) to estimate the $\mathrm{Vs}_{30}$ profiles of the topmost $30 \mathrm{~m}$. The shot records were insulated from the refracted and reflected waves by muting at first and afterward. It was filtered $2-4,36-48 \mathrm{~Hz}$ band-pass filter to remove low and high frequency noise (Figure 5(a). Later, plane wave decomposition was applied to transform the data from offset time to phase the velocity-against frequency domain [33, 34]. 
The dispersive curve of the fundamental mode of surface waves are picked from this domain. S-wave velocity as a function of depth was determined to invert the dis- persion curve. For the fundamental mode, the dispersion curve representing the variation of the phase velocity with respect to frequency is determined as shown.

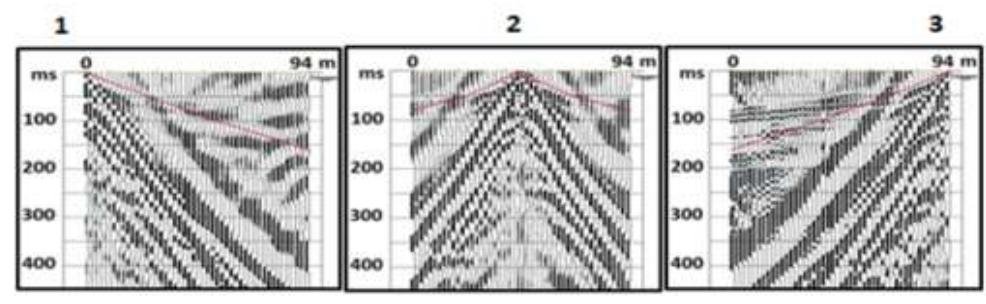

(a)

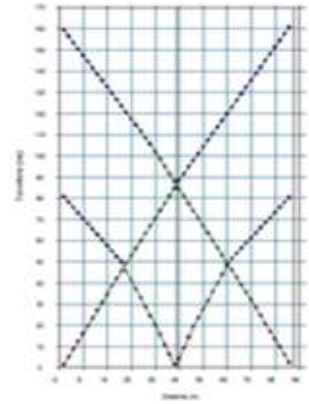

(b)

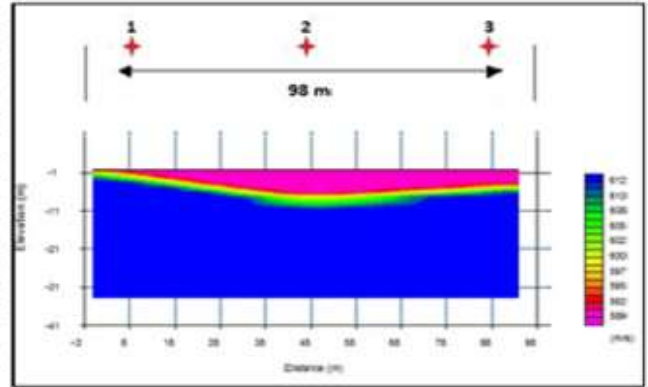

(c)

Fig. 4. (a) Seismic refraction records with picked firstarrival times showing in redline collected at the station no:0117 (b) travel time curves of mid-point shot, (c) P-wave velocity-depth model

This dispersion curve was used to determine the Swave velocity-depth profile of the stationary zone and the $\mathrm{S}$-wave velocity-depth profile by the inversion method
(Figure 5(b).The dispersion curve showing the variation of the frequency and phase velocity for the basic mode is shown in Figure 5(c).

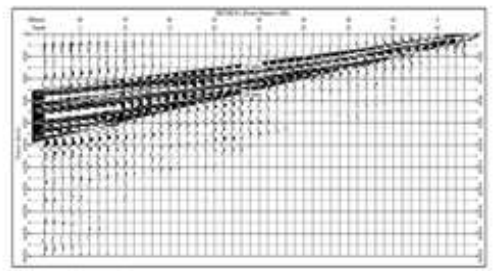

(a)

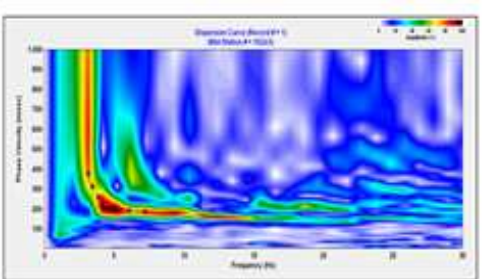

(b)

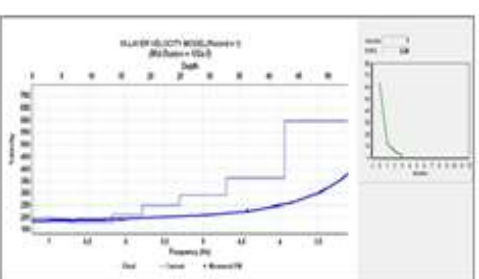

(c)

Fig. 5. (a) the shot record separated from the refraction and reflected waves at 0117 coded stations, (b) MASW dispersion spectrum of the surface waves. The MASW S-wave-depth profile (blue) and the modeled dispersion curve (black), (c) Vs-depth profile and modeled dispersion curve. 
The ReMi data were recorded as 32 seconds with a sampling rate of $2 \mathrm{sec}$ with the same field pattern as the seismic source, usually using ambient noise from the wind and traffic. 24-25 records are stacked in each ReMi installation. Rayleigh waves are distinguished from other waves using two-dimensional slowness frequencies ( $\mathrm{p}-\mathrm{f}$ ) transforms of noise recordings in both directions. The Rayleigh wave dispersion is selected along the minimum velocity envelope of the energy in the slowness frequency spectral image. These Rayleigh wave dis- persion curves are modeled by using the velocity-depth model to determine the shear wave velocity depth profile. The time-distance data are shown in Figure 6(a). The dispersive curve of the basic mode of surface waves is taken from this domain. S-wave velocity as a function of depth was determined inverting the dispersion curve (Figure 6(b)).This dispersion curve was used to determine the S-wave velocity-depth profile of the stationary zone by the inversion method Figure 6(c).

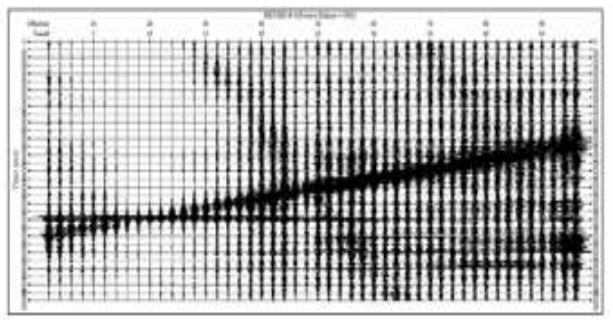

(a)

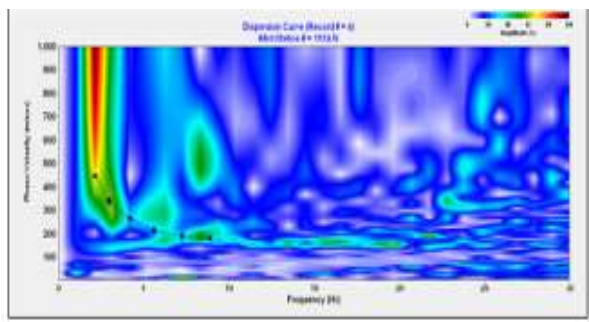

(b)

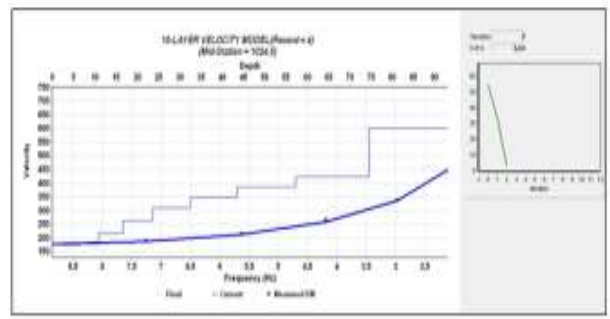

(c)

Fig. 6. (a) ReMi data at 0117 coded station, (b) the dispersion spectrum calculated by separating the plane-wave components of the surface waves present in the seismic record, (c) S-wave velocity-depth profile (blue) and modeled dispersion curve (black). The vertical axis indicates the S-wave velocity and the horizontal axis shows the frequency of the dispersion curve.

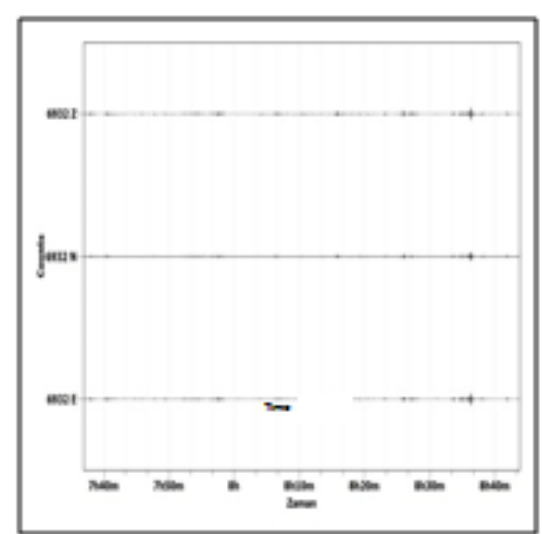

(a)

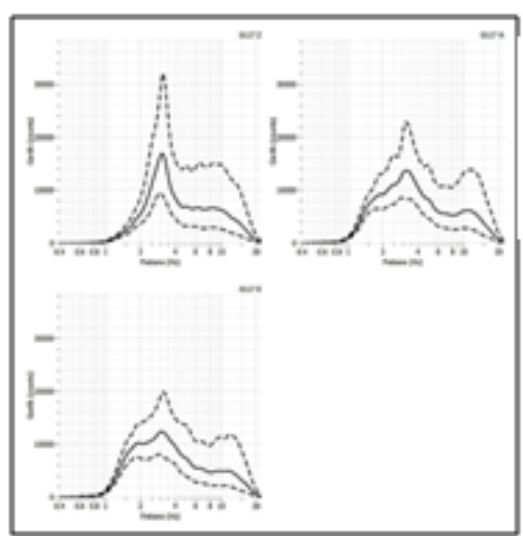

(b)

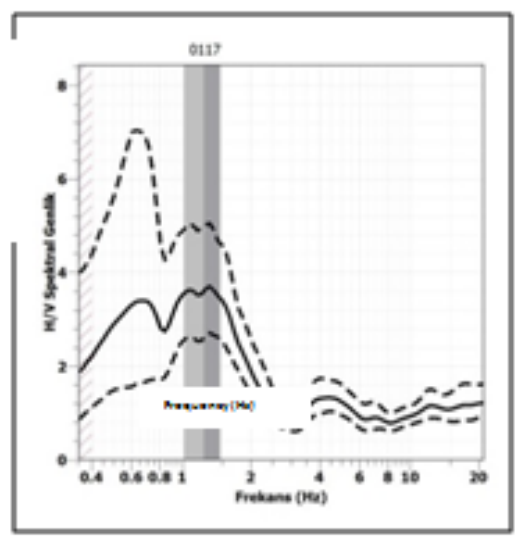

(c)

Fig. 7. a) Filtered time signal series, b) The amplitude spectra of the three components microtremor data the peak and (c) the H/V amplitude spectrums. The dashed lines show the standard deviation of amplitude and the two vertical gray areas indicate the peak frequency standard deviation domains. 
The velocity-based broadband sensor $(0.03-50 \mathrm{~Hz}$ straight response) was used for ambition noise recording. Whole data were recorded with the same sensor Figure 7(a) and Figure 7(b). The H/V amplitude spectrum of the dominant frequency and the amplification of the 0117 coded stations is shown in Figure 7(c). As depicted in Figure 7, the microtremor dominant period is 0.80 seconds with $1.125 \mathrm{~Hz}$ frequency, and $\mathrm{H} / \mathrm{V}$ peak amplitude values were 3.6. The predominant period of the region ranges from 0.07 to $1.47 \mathrm{~s}$ and the dominant magnification values vary between 0.79 and 8.5.

\section{A. Site Classification for the Investigation Area}

MASW, ReMi, and microtremor methods were conducted at 65 stations and $\mathrm{Vs}_{30}$ velocity profiles were determined for the uppermost $30 \mathrm{~m}$. The $\mathrm{Vs}_{30}$ values range from 191 to $1822 \mathrm{~m} / \mathrm{s}$. The lower velocities are generally determined on the plain areas (Figure 8 and Table 1).

TABLE 1

LIST OF THE CLASSES FOR THE STRONG MOTION STATIONS IN AKDENIZ PROVINCE

\begin{tabular}{|c|c|c|c|c|c|c|c|c|c|c|c|}
\hline & $\begin{array}{l}\text { Sta- } \\
\text { tion } \\
\text { Code }\end{array}$ & Station Name & Lat $\left({ }^{\circ} \mathrm{N}\right)$ & Lon $\left({ }^{\circ} \mathrm{E}\right)$ & $\begin{array}{l}\mathrm{Vs}_{30} \\
(\mathrm{~m} / \mathrm{s})\end{array}$ & $\begin{array}{l}\mathrm{H} / \mathrm{V} \text { peak } \\
\text { amplitude }\end{array}$ & $\begin{array}{l}\text { Predominant } \\
\text { period }(\mathrm{sn})\end{array}$ & [1] & [2] & [3] & [4] \\
\hline 1 & 101 & STATION & 37,044 & 35,226 & 478 & 3.7 & 1.47 & $\mathrm{C}$ & B & $\mathrm{ZC}$ & D-3 \\
\hline 2 & 102 & STATİON & 37.05792 & 35.36698 & 417 & 3.05 & 0.21 & $\mathrm{C}$ & B & $\mathrm{ZC}$ & C-1 \\
\hline 3 & 103 & STATION & 36.995811 & 35.3706 & 423 & 1.01 & 0.20 & $\mathrm{C}$ & $\mathrm{B}$ & $\mathrm{ZC}$ & C-1 \\
\hline 4 & 106 & CEYHAN & 36.908 & 35.567 & 210 & 3.15 & 0.55 & $\mathrm{D}$ & $\mathrm{C}$ & ZD & C-3 \\
\hline 5 & 107 & CEYHAN & 37.033 & 35.633 & 405 & 3.1 & 0.67 & $\mathrm{C}$ & B & $\mathrm{ZC}$ & $\mathrm{C}-3$ \\
\hline 6 & 108 & CEYHAN & 36.876 & 35.617 & 654 & 2.00 & 0.14 & $\mathrm{C}$ & B & $\mathrm{ZC}$ & C-1 \\
\hline 7 & 109 & CEYHAN & 37.178 & 35.689 & 253 & 2.7 & 1.17 & $\mathrm{D}$ & $\mathrm{C}$ & ZD & D-2 \\
\hline 8 & 111 & SEYHAN & 37.166 & 35.226 & 461 & 0.79 & 0.43 & $\mathrm{C}$ & B & $\mathrm{ZC}$ & $\mathrm{C}-2$ \\
\hline 9 & 112 & YUREGIR & 36.871580 & 35.476279 & 490 & 1.6 & 0.57 & $\mathrm{C}$ & B & $\mathrm{ZC}$ & $\mathrm{C}-3$ \\
\hline 10 & 113 & YUREGIR & 36.955522 & 35.627320 & 267 & 3.11 & 0.50 & $\mathrm{D}$ & $\mathrm{C}$ & ZD & C-3 \\
\hline 11 & 114 & YUREGIR & 37.175843 & 35.69286 & 483 & 1.05 & 0.66 & $\mathrm{C}$ & B & $\mathrm{ZC}$ & C-3 \\
\hline 12 & 115 & YUREGIR & 37.081210 & 35.454380 & 322 & 2.1 & 1.01 & $\mathrm{D}$ & $\mathrm{C}$ & ZD & D-2 \\
\hline 13 & 116 & YUREGIR & 37.104862 & 35.462624 & 466 & 0.8 & 0.55 & B & $\mathrm{C}$ & ZB & C-3 \\
\hline 14 & 117 & YUREGİR & 36.838383 & 35.241111 & 215 & 3.6 & 0.80 & $\mathrm{D}$ & $\mathrm{C}$ & ZD & D-2 \\
\hline 15 & 120 & YUREGIR & 36.77006 & 35.79005 & 439 & 3.1 & 0.16 & $\mathrm{C}$ & B & $\mathrm{ZC}$ & C-1 \\
\hline 16 & 122 & KOZAN & 37.4339 & 35.82021 & 501 & 3.1 & 0.13 & $\mathrm{C}$ & B & $\mathrm{ZC}$ & C-1 \\
\hline 17 & 123 & YUREGIR & 37.00338 & 35.34376 & 519 & 6.7 & 0.2 & $\mathrm{C}$ & B & $\mathrm{ZC}$ & C-1 \\
\hline 18 & 124 & POZANTI & 37.4087 & 34.87911 & 583 & 5.8 & 0.16 & $\mathrm{C}$ & B & $\mathrm{ZC}$ & C-1 \\
\hline 19 & 125 & CEYHAN & 37.01519 & 35.79577 & 216 & 1.94 & 1.03 & $\mathrm{D}$ & $\mathrm{C}$ & $\mathrm{ZD}$ & D-2 \\
\hline 20 & 126 & ALADAG & 37.54551 & 35.39186 & 521 & 2.4 & 0.22 & $\mathrm{C}$ & $\mathrm{B}$ & $\mathrm{ZC}$ & $\mathrm{C}-1$ \\
\hline 21 & 127 & FEKE & 37.81619 & 35.92038 & 583 & 3.3 & 0.16 & $\mathrm{C}$ & B & $\mathrm{ZC}$ & B \\
\hline 22 & 128 & KARAİSALİ & 37.25029 & 35.06279 & 494 & 2.3 & 0.8 & $\mathrm{C}$ & B & $\mathrm{ZC}$ & D-1 \\
\hline 23 & 129 & TUFANBEYLİ & 38.25915 & 36.21013 & 965 & 2.1 & 0.1 & B & A & ZB & B \\
\hline 24 & 707 & KORKUTELİ & 37.0007 & 30.35028 & 1822 & 3.8 & 1.47 & A & A & ZA & $\mathrm{C}-2$ \\
\hline 25 & 713 & ALANYA & 36.54286 & 32.00434 & 540 & 2.4 & 0.47 & $\mathrm{C}$ & B & $\mathrm{ZC}$ & $\mathrm{C}-2$ \\
\hline 26 & 714 & ALANYA & 36.55547 & 31.98667 & 607 & 1.4 & 0.47 & $\mathrm{C}$ & $\mathrm{B}$ & $\mathrm{ZC}$ & $\mathrm{C}-2$ \\
\hline 27 & 715 & $\begin{array}{l}\text { MAHMUT- } \\
\text { LAR }\end{array}$ & 36.48778 & 32.09627 & 285 & 4.8 & 0.8 & $\mathrm{D}$ & $\mathrm{C}$ & $\mathrm{ZD}$ & D-2 \\
\hline 28 & 716 & KALKAN & 36.2685 & 29.4128 & 813 & $<2$ & $0.5-0.1$ & B & A & $\mathrm{ZB}$ & \\
\hline 29 & 717 & KEPEZ & 36.9495 & 30.6419 & 724 & 1.7 & 0.19 & $\mathrm{C}$ & B & $\mathrm{ZC}$ & $\mathrm{C}-1$ \\
\hline 30 & 1506 & GOLHİSAR & 37.14721 & 29.50946 & 337 & 1.6 & 0.58 & $\mathrm{D}$ & $\mathrm{C}$ & ZD & $\mathrm{C}-3$ \\
\hline 31 & 1507 & KOZLUCA & 37.4942 & 30.1336 & 359 & 0.8 & 1.1 & $\mathrm{D}$ & $\mathrm{C}$ & $\mathrm{ZD}$ & $\mathrm{C}-3$ \\
\hline 32 & 1508 & SOGUT & 37.0363 & 29.8214 & 206 & 1.4 & 0.23 & $\mathrm{D}$ & $\mathrm{C}$ & ZD & D-1 \\
\hline 33 & 3111 & $\begin{array}{l}\text { KİRİKHAN } \\
\text { TOPBOGAZI }\end{array}$ & 36,00 & 36,30164 & 191 & 1.6 & 1.06 & $\mathrm{D}$ & $\mathrm{C}$ & $\mathrm{ZD}$ & D-2 \\
\hline 34 & 3112 & İSKENDERUN & 36,58801 & 36,14766 & 233 & 6.6 & 0.2 & $\mathrm{D}$ & $\mathrm{C}$ & ZD & $\mathrm{C}-2$ \\
\hline 35 & 3113 & İSKENDERUN & 36,57752 & 36,15496 & 221 & 0.8 & 0.67 & $\mathrm{D}$ & $\mathrm{C}$ & ZD & $\mathrm{C}-3$ \\
\hline 36 & 3114 & İSKENDERUN & 36,56704 & 36,15135 & 215 & 3.2 & 1.35 & $\mathrm{D}$ & $\mathrm{C}$ & $\mathrm{ZD}$ & C-3 \\
\hline 37 & 3115 & İSKENDERUN & 36,54634 & 36,16459 & 414 & 2.5 & 1.1 & $\mathrm{C}$ & B & $\mathrm{ZC}$ & D-2 \\
\hline 38 & 3116 & İSKENDERUN & 36,61618 & 36,20661 & 870 & 1.6 & 0.23 & $\mathrm{~B}$ & B & $\mathrm{ZB}$ & $\mathrm{C}-1$ \\
\hline 39 & 3117 & İSKENDERUN & 36,55712 & 36,17471 & 597 & 2.2 & 0.24 & $\mathrm{C}$ & B & $\mathrm{ZC}$ & $\mathrm{C}-1$ \\
\hline
\end{tabular}


TABLE 1 CONTINUEE

\begin{tabular}{|c|c|c|c|c|c|c|c|c|c|c|c|}
\hline & $\begin{array}{l}\text { Sta- } \\
\text { tion } \\
\text { Code }\end{array}$ & Station Name & Lat $\left({ }^{\circ} \mathrm{N}\right)$ & Lon $\left({ }^{\circ} \mathrm{E}\right)$ & $\begin{array}{l}\mathrm{Vs}_{30} \\
(\mathrm{~m} / \mathrm{s})\end{array}$ & $\begin{array}{l}\mathrm{H} / \mathrm{V} \text { peak } \\
\text { amplitude }\end{array}$ & $\begin{array}{l}\text { Predominant } \\
\text { period (sn) }\end{array}$ & [1] & [2] & [3] & [4] \\
\hline 40 & 3119 & İSKENDERUN & 36,57527 & 36,16811 & 374 & 3.2 & 0.2 & $\mathrm{C}$ & B & $\mathrm{ZC}$ & $\mathrm{C}-1$ \\
\hline 41 & 3120 & İSKENDERUN & 36,58924 & 36,20568 & 455 & 3.1 & 0.26 & $\mathrm{C}$ & B & $\mathrm{ZC}$ & C-1 \\
\hline 42 & 3121 & İSKENDERUN & 36,66408 & 36,21825 & 271 & 8.5 & 0.43 & $\mathrm{D}$ & $\mathrm{C}$ & ZD & C-3 \\
\hline 43 & 3122 & YAYLADAG & 36,0343 & 36,107 & 1011 & 2.1 & 0.19 & B & A & ZB & B \\
\hline 44 & 3124 & ANTAKYA & 36,2387 & 36,1722 & 283 & 4.1 & 0.81 & $\mathrm{D}$ & $\mathrm{C}$ & ZD & D-1 \\
\hline 45 & 3125 & ANTAKYA & 36,23808 & 36,13264 & 448 & 5.2 & 1.06 & $\mathrm{C}$ & $\mathrm{B}$ & $\mathrm{ZC}$ & D-1 \\
\hline 46 & 3126 & ANTAKYA & 36,2202 & 36,1375 & 350 & 2.06 & 0.16 & $\mathrm{D}$ & $\mathrm{C}$ & ZD & C-3 \\
\hline 47 & 3127 & ANTAKYA & 36,21 & 36,1353 & 404 & 3.6 & 0.12 & $\mathrm{C}$ & B & $\mathrm{ZC}$ & B \\
\hline 48 & 3128 & ANTAKYA & 36,2056 & 36,1471 & 329 & 2.4 & 0.3 & $\mathrm{D}$ & $\mathrm{C}$ & ZD & D-1 \\
\hline 49 & 3129 & ANTAKYA & 36,19117 & 36,1343 & 447 & 2.06 & 0.07 & $\mathrm{C}$ & B & $\mathrm{ZC}$ & $\mathrm{C}-1$ \\
\hline 50 & 3130 & ANTAKYA & 36,1792 & 36,145 & 447 & 3.2 & 0.07 & $\mathrm{C}$ & B & $\mathrm{ZC}$ & B \\
\hline 51 & 3131 & ANTAKYA & 36,19121 & 36,16328 & 567 & 4.3 & 0.59 & $\mathrm{C}$ & $\mathrm{B}$ & $\mathrm{ZC}$ & C-3 \\
\hline 52 & 3132 & ANTAKYA & 36,20673 & 36,17159 & 377 & 2.49 & 0.29 & $\mathrm{C}$ & B & $\mathrm{ZC}$ & $\mathrm{C}-1$ \\
\hline 53 & 3133 & ANTAKYA & 36,2432 & 36,5736 & 377 & 4.6 & 1.19 & $\mathrm{C}$ & B & $\mathrm{ZC}$ & D-2 \\
\hline 54 & 3134 & DORTYOL & 36,82763 & 36,20485 & 374 & 1.8 & 1.04 & $\mathrm{C}$ & $\mathrm{B}$ & $\mathrm{ZC}$ & D-2 \\
\hline 55 & 3135 & ULUCINAR & 36,40886 & 35,8831 & 460 & 2.9 & 0.1 & $\mathrm{C}$ & $\mathrm{B}$ & $\mathrm{ZC}$ & $\mathrm{C}-2$ \\
\hline 56 & 3143 & $\begin{array}{l}\text { HASSA } \\
\text { AKBEZ }\end{array}$ & 36,84891 & 36,55714 & 444 & 2.2 & 1.42 & $\mathrm{C}$ & B & $\mathrm{ZC}$ & D-2 \\
\hline 57 & 3144 & $\begin{array}{l}\text { HASSA } \\
\text { HACİLAR }\end{array}$ & 36,75746 & 36,48601 & 485 & 2.2 & 1.1 & $\mathrm{C}$ & $\mathrm{B}$ & $\mathrm{ZC}$ & D-2 \\
\hline 58 & 3145 & $\begin{array}{l}\text { KİRIKHHAN } \\
\text { BALARMUDU }\end{array}$ & 36,64537 & 36,40642 & 533 & 1.68 & 0.47 & $\mathrm{C}$ & $\mathrm{B}$ & $\mathrm{ZC}$ & $\mathrm{C}-2$ \\
\hline 59 & 3302 & AKKUYU & 36.1613 & 33.57584 & 1007 & 2.2 & 0.41 & B & A & ZB & C-2 \\
\hline 60 & 3303 & CAMLIYAYLA & 37.1659 & 34.60043 & 612 & 2.09 & 0.25 & $\mathrm{C}$ & B & $\mathrm{ZC}$ & $\mathrm{C}-1$ \\
\hline 61 & 3304 & SILİFKE & 36.38226 & 33.93664 & 297 & 2.2 & 1.47 & $\mathrm{D}$ & $\mathrm{C}$ & ZD & E-2 \\
\hline 62 & 3305 & TARSUZ & 39.92142 & 34.89897 & 362 & 3.7 & 0.24 & $\mathrm{C}$ & B & $\mathrm{ZC}$ & $C-1$ \\
\hline 63 & 3306 & MUT & 36.64169 & 33.43956 & 490 & 4.7 & 0.1 & $\mathrm{C}$ & $\mathrm{B}$ & $\mathrm{ZC}$ & $\mathrm{B}$ \\
\hline 64 & 3307 & ANAMUR & 36.08189 & 32.84224 & 855 & 1.2 & 0.1 & $\mathrm{~B}$ & $\mathrm{~A}$ & $\mathrm{ZB}$ & B \\
\hline 65 & 8004 & KADİRLİ & 37.37992 & 36.09757 & 426 & 2.2 & 0.13 & $\mathrm{C}$ & B & $\mathrm{ZC}$ & B \\
\hline
\end{tabular}

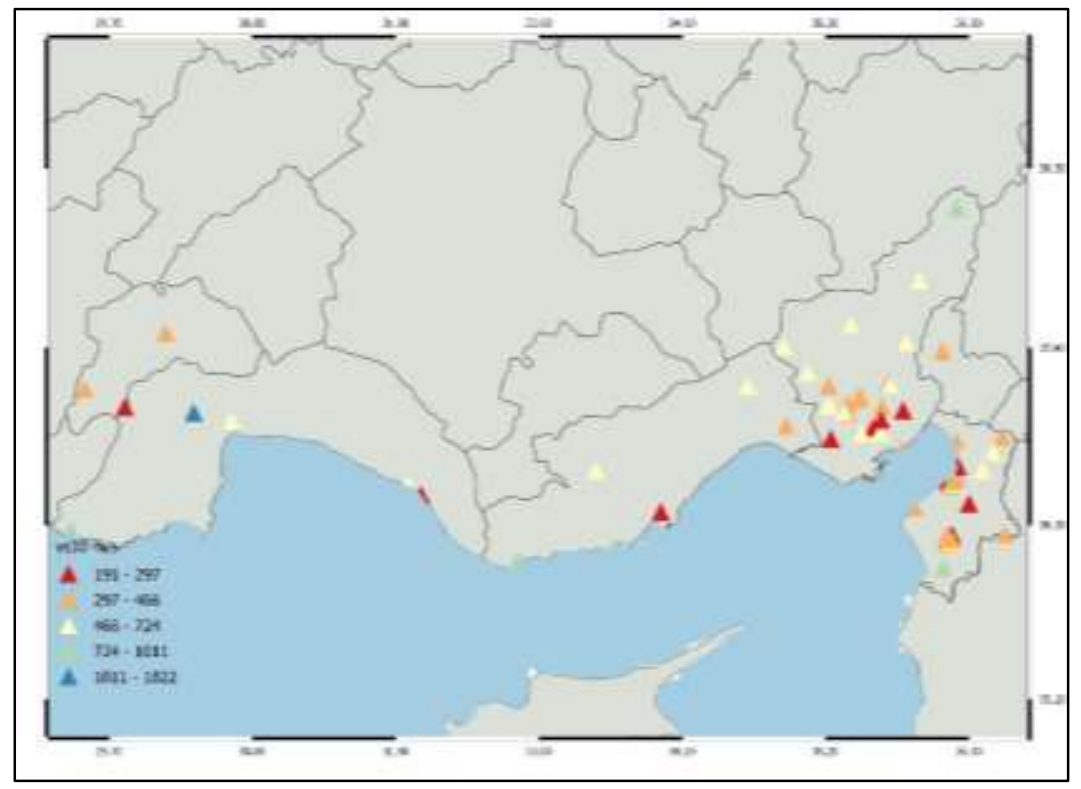

Fig. 8. S-wave, $\mathrm{Vs}_{30}$, distribution in the Akdeniz region 
The sites were classified in accordance with NEHRP Provisions [1], Eurocode-8 [2], TBDY [3] and Rodrigez and Marez (2001), (Table 1). The NEHRP Provisions suggest six site classes such as A, B, C, D, E, and F for the recognition of site conditions. 1 station is classified as class A, 7 stations as B and 38 stations as C and 19 stations to be class D. According to Eurocode-8 [2], 6 stations correspond to class A, 39 stations $\mathrm{B}$, and 20 stations $\mathrm{D}$ which are similar to NEHRP provision. The classes of $\mathrm{C}, \mathrm{B}$, and $\mathrm{A}$ in NEHRP correspond to classes of B, A, and $\mathrm{C}$ in Eurocode- 8 system since the boundary values of class $C$ in the NEHRP system coincide with the boundary values of class B in Eurocode-8, the boundary values of class B come up to the boundary values of class A and the boundary values of class $\mathrm{D}$ match with the boundary values of class $C$. The soil classes in the NEHRP system correspond to that of TBDY-2018 as seen in Table 1. According to [4] soil classifications, 8 stations are classified as A, 17 stations $\mathrm{B}, 8$ stations $\mathrm{C}-1,13$ stations $\mathrm{C}-2,5$ stations C-3,11 stations D-1, 1 station D-2, 1 station D-3, 1 station $\mathrm{E}$ and 1 station is undistinguished (Figure 9, Figure 10, Figure 11, Figure 12).

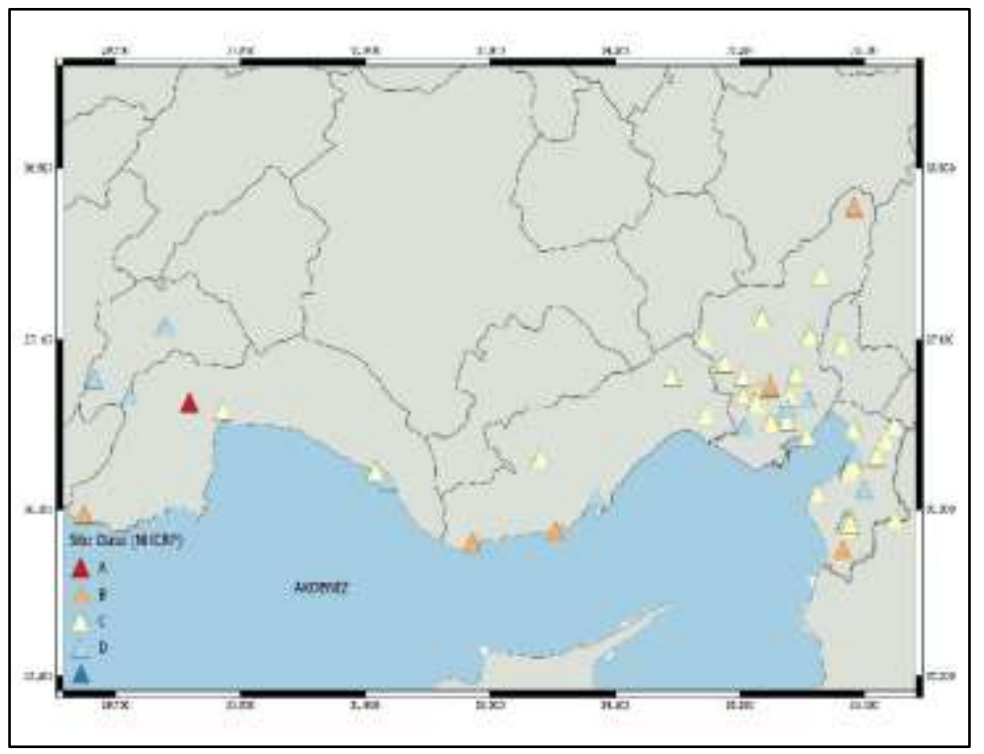

Fig. 9. NEHRP classification of the Akdeniz region

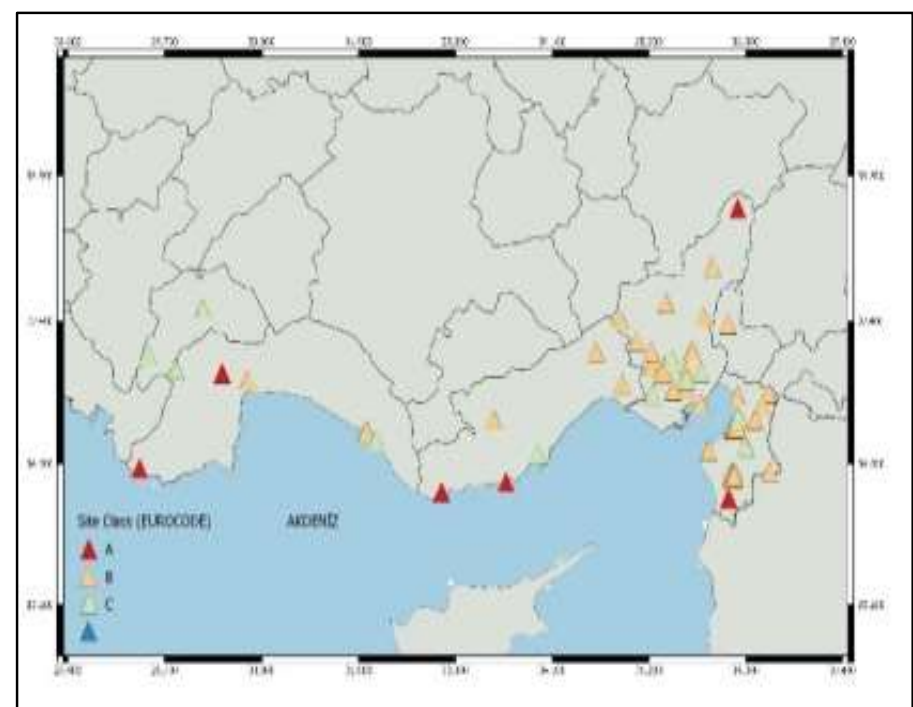

Fig. 10. Eurocode-8 classification of the Akdeniz region

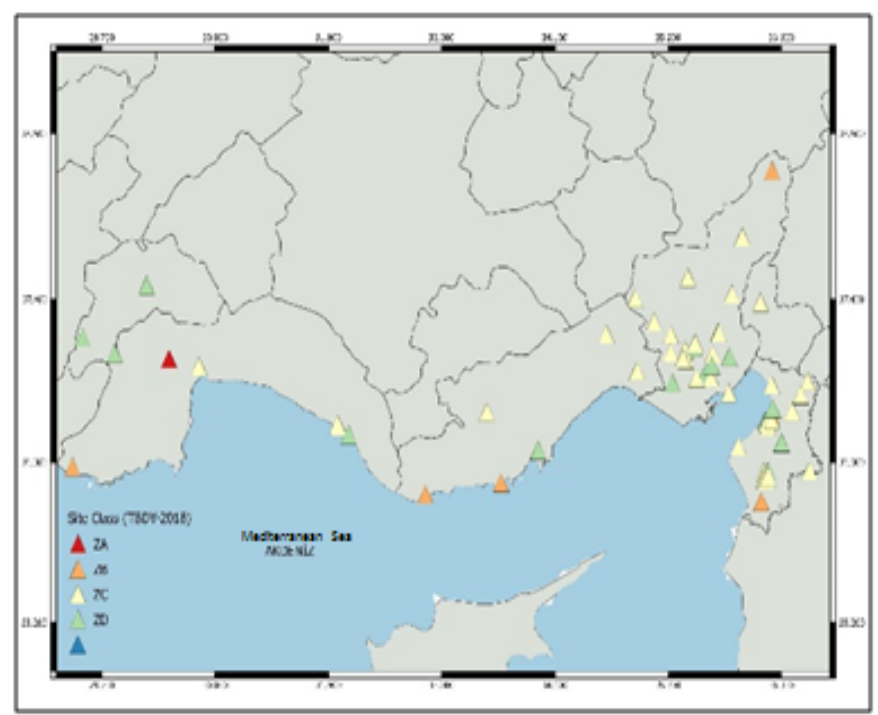

Fig. 11. TBDY classification of the Akdeniz region 


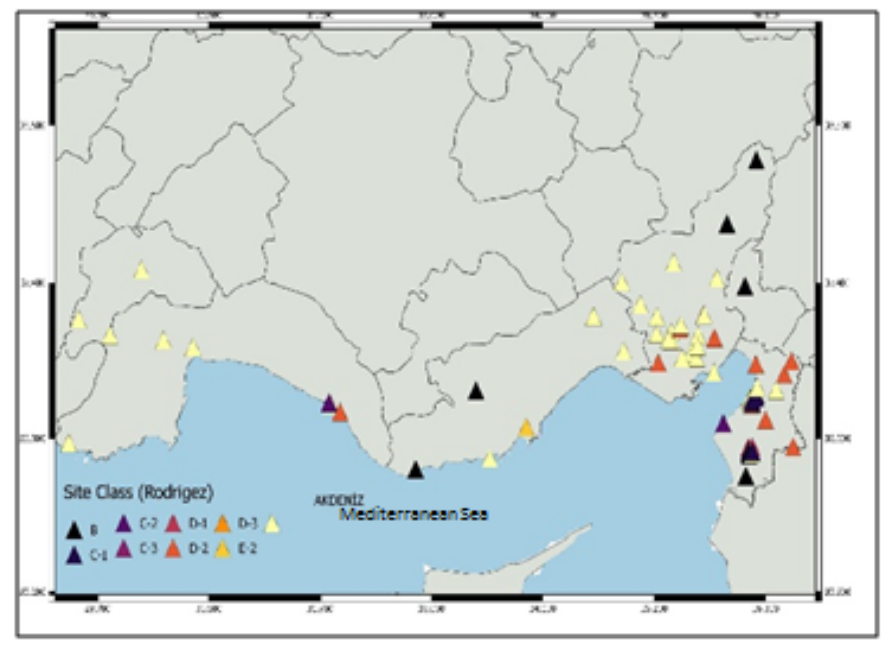

Fig. 12. Rodrigez and Marez classification of the Akdeniz region

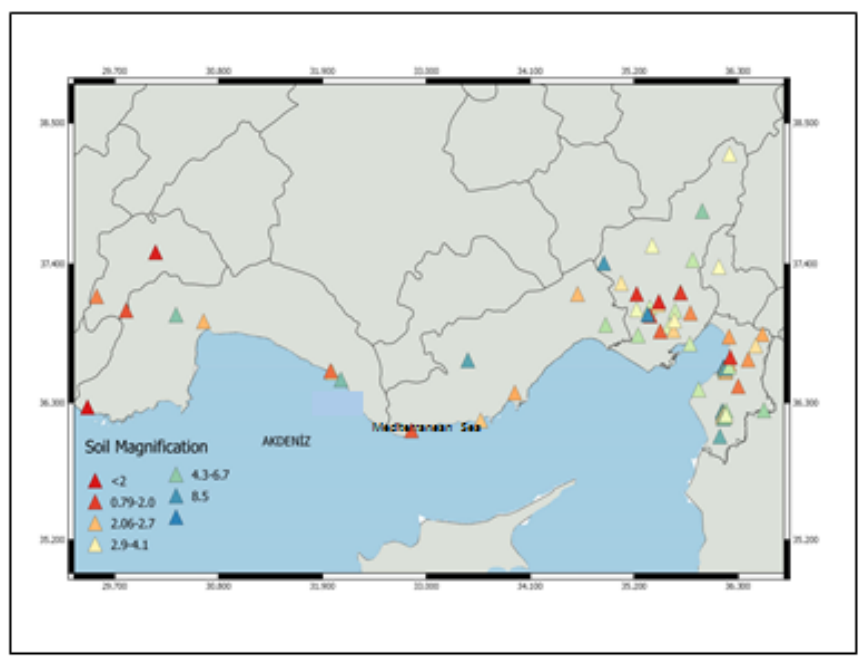

Fig. 13. Soil magnification of the Akdeniz region

\section{B. Site amplification properties of Akdeniz region}

Amplification ratios (H/V) and predominant periods were determined at 65 stations. Soil amplification and predominant periods were interpreted by Geopsy2004 software. The $\mathrm{H} / \mathrm{V}$ ratios were determined between 0.79-8.5. The small magnification values (0.79-2.3) are generally observed on the stations located on the mountains, and higher values (2.3-8.5) were found in plain areas (Figure 13).

\section{DISCUSSION AND CONCLUSION}

The $\mathrm{Vs}_{30}$ values range from 191 to $1822 \mathrm{~m} / \mathrm{s}$ which are similar to the velocities determined by [29] in the Hatay province of this region. The lower velocities are generally determined on the plain areas. The lowest $\mathrm{Vs}_{30}$ value was determined at 0117 coded Topbogazi station and the highest value at 707 coded Korkuteli station. The Akdeniz region was classified according to NEHRP Pro- visions [1], Eurocode-8 [2], Turkish Building Earthquake Regulations [3] and [4]. According to NEHRP classification system the soil class of 38 stations is C and 19 stations is D indicating weak soil types. In this system only 1 station is determined as class A indicating strong soil and 7 stations indicating moderately hard soil. The soil classes in the NEHRP system correspond to that of TBDY-2018. According to Eurocode-8, 6 stations correspond to class A, 39 stations B, and 20 stations D which are similar to NEHRP provision. According to [4] soil classification; 8 stations are classified as A, 17 stations B, 8 stations $\mathrm{C}-1,13$ stations $\mathrm{C}-2,5$ stations $\mathrm{C}-3,11$ stations D-1, 1 station D-2, 1 station D-3, 1 station $E$ and 1 station is undistinguished. The soil amplification values were determined between 0.7 and $8.5 \mathrm{sec}$. The lowest amplification value is observed at 111 coded Seyhan station and the highest at 3121 coded Iskenderun station. The higher amplification values are generally obtained on the plain areas. These values are in good agreement with the values determined by [29]. The max and the min predominant periods were determined as $0.07 \mathrm{sec}$ at 3129 and 3130 coded stations and $1.47 \mathrm{sec}$ at 101, 707 and 3304 coded stations. Predominant periods of values generally increase with decreasing $\mathrm{Vs}_{30}$ velocities.

The results determined in this study formed the basis of the site properties of the Akdeniz region. However; more studies are necessary to define the detailed site characteristics of the region.

\section{REFERENCES}

[1] Building Seismic Safety Council, "NEHRP recommended provisions for seismic regulations for new buildings and other structures part 1: Provisions," National institute of building sciences, Washington, DC, WA, Tech. Rep., 2003.

[2] P. Bisch, E. Carvalho, H. Degee, P. Fajfar, M. Fardis, P. Franchin, M. Kreslin, A. Pecker, P. Pinto, A. Plumier, H. Somja, and G. Tsionis, "Eurocode 8: Seismic design of buildings worked examples," European Commission, Brussels, Belgium, Tech. Rep., 2012.

[3] TBDY. (2018) Turkey building earthquake regulation. [Online]. Available: https://bit.ly/2Dxgafu

[4] A. Rodriguez-Marek, J. D. Bray, and N. A. Abrahamson, "An empirical geotechnical seismic site response procedure," Earthquake Spectra, vol. 17, no. 1, pp. 65-87, 2001. doi: https://doi.org/10.1193/ 1.1586167

[5] B. Kemal, E. Mustafa, M. Cihat, and E. Zahi, "Seismic from the past to the presentthe activity and what to do in the light of the international conference eval- 
uation," Turkish Engineer News, vol. 1, no. 423, pp. 51-53, 2003.

[6] U. Tarı, O. Tüysüz, Ş. Can Genç, C. İmren, B. A. Blackwell, N. Lom, Ö. Tekeşin, S. Üsküplü, L. Erel, S. Altiok et al., "The geology and morphology of the Antakya Graben between the Amik Triple Junction and the Cyprus Arc," Geodinamica Acta, vol. 26, no. 1-2, pp. 27-55, 2013. doi: https://doi.org/10.1080/ 09853111.2013 .858962

[7] R. C. Ates and N. Bayülke, "The 19 August 1976 Denizli, Turkey, earthquake: Evaluation of the strong motion accelerograph record," Bulletin of the Seismological Society of America, vol. 72, no. 5, pp. 1635-1649, 1982.

[8] N. N. Ambraseys, E. Durukal, and M. Free, "Reevaluation of strong-motion data from Turkey," Imperial College of Science, Technology and Medicine, London, UK, ESEE Research Report, No. 93/2, 1993.

[9] O. Aydan and Z. Hasgür, "The characteristics of acceleration waves of Turkish earthquakes," In Proceedings of the 4th National Conference on Earthquake Engineering, Ankara, Turkey, 1997.

[10] M. Celebi, S. Akkar, U. Gulerce, A. Sanli, H. Bundock, and A. Salkin, "Main shock and aftershock records of the 1999 Izmit and Duzce, Turkey earthquakes," U.S. Geological Survey, Reston, VA, Tech. Rep., 2001.

[11] E. Durukal, Y. Alpay, T. Biro, A. Mert, and M. Erdik, "Analysis of strong motion data of the 1995 Dinar, turkey earthquake, second Japan-Turkey workshop: Earthquake disaster prevention research in Turkey," Istanbul Technical University, stanbul, Turkey, Tech. Rep., 1998.

[12] M. Erdik and E. Durukal, "1999 Kocaeli and Düzce, Turkey earthquakes: Strong ground motion," In XV ICSMGE TC4 Satellite Conference on Lessons Learned from Recent Strong Earthquakes, Istanbul, Turkey, 1999.

[13] M. Zaré and P.-Y. Bard, "Strong motion dataset of Turkey: Data processing and site classification," Soil Dynamics and Earthquake Engineering, vol. 22, no. 8, pp. 703-718, 2002. doi: https://doi.org/10. 1016/s0267-7261(02)00028-3

[14] S. Ozalaybey, M. Ergin, M. Aktar, C. Tapirdamaz, F. Biçmen, and A. Yoruk, "The 1999 Izmit earthquake sequence in Turkey: Seismological and tectonic aspects," Bulletin of the Seismological Society of America, vol. 92, no. 1, pp. 376-386, 2002. doi: https://doi.org/10.1785/0120000838

[15] E. M. Rathje, K. H. Stokoe, and B. Rosenblad,
"Strong motion station characterization and site effects during the 1999 earthquakes in Turkey," Earthquake Spectra, vol. 19, no. 3, pp. 653-675, 2003. doi: https://doi.org/10.1193/1.1596212

[16] M. Ergin, M. Aktar, and H. Eyidogan, "Presentday seismicity and seismotectonics of the Cilician Basin: Eastern Mediterranean Region of Turkey," Bulletin of the Seismological Society of America, vol. 94, no. 3, pp. 930-939, 2004. doi: https: //doi.org/10.1785/0120020153

[17] D. Kalafat, Y. Güneş, M. Kara, P. Deniz, K. Kekovalı, H. Kuleli, L. Gülen, M. Yılmazer, and N. Özel, "A revised and extended earthquake catalogue for Turkey since 1900 ( $\mathrm{m} \geq 4$ 4.0)," mathesis, Bogaziçi University, Istanbul, Turkey, 2007.

[18] Ö. Erdoğan, "Main seismological features of recently compiled Turkish strong motion database," Middle East Technical University, Ankara, Turkey, Tech. Rep., 2008.

[19] M. A. Sandkkaya, "Site classification of national strong-motion recording sites," mathesis, Civil Engineering Department, Middle East Technical University, Ankara, Turkey, 2008.

[20] M. A. Sandıkkaya, M. T. Yılmaz, B. S. Bakır, and Ö. Yılmaz, "Site classification of Turkish national strong-motion stations," Journal of Seismology, vol. 14, no. 3, pp. 543-563, 2010. doi: https: //doi.org/10.1007/s10950-009-9182-y

[21] E. Kalkan and P. Gulkan, "Site-dependent spectra derived from ground motion records in Turkey," Earthquake Spectra, vol. 20, no. 4, pp. 1111-1138, 2004. doi: https://doi.org/10.1193/1.1812555

[22] R. Ulusay, E. Tuncay, H. Sonmez, and C. Gokceoglu, "An attenuation relationship based on turkish strong motion data and isoacceleration map of Turkey," Engineering Geology, vol. 74, no. 3-4, pp. 265-291, 2004. doi: https://doi.org/10.1016/j.enggeo.2004.04.002

[23] Ö. Yılmaz, E. Savaşkan, B. Bakır, M. Yılmaz, M. Eser, S. Akkar, B. Tüzel, Y. Iravul, Ö. Özmen, and Z. Denizlioğlu, "Shallow seismic and geotechnical site surveys at the Turkish national grid for strong-motion seismograph stations," In Proceedings14th World Conference on Earthquake Engineering, Beijing, China, 2008.

[24] P. Gulkan, U. Ceken, Z. Colakoglu, T. Ugras, T. Kuru, A. Apak, J. Anderson, H. Sucuoglu, M. Celebi, D. Akkar et al., "Enhancement of the national strong-motion network in Turkey," Seismological Research Letters, vol. 78, no. 4, pp. 429-438, 2007. 
[25] S. Över, A. Büyüksaraç, Ö. Bekta, and A. Filazi, "Assessment of potential seismic hazard and site effect in Antakya (Hatay Province), SE Turkey," Environmental Earth Sciences, vol. 62, no. 2, pp. 313-326, 2011. doi: https://doi.org/10.1007/ s12665-010-0525-3

[26] H. Korkmaz, "Between antiquity soil properties and earthquake effect," Journal of Relationships, Geographical Sciences, vol. 4, no. 2, pp. 49-66, 2006.

[27] S. Ş. Horoz, "Analysis of the seismicity of the region between adana-antakya-kahramanmara with the parameter ' $b$ ' kahraman and risk analysis." Cumhuriyet University, Sivas, Turkey, Tech. Rep., 2008.

[28] O. Polat and U. Çeken, "Investigation of the local soil effects at the new strong-motion array (MATNet) in Hatay-K. Maras Region, Turkey," In $A G U$ Fall Meeting, San Francisco, CA, 2014.

[29] Ö. T. Özmen, H. Yamanaka, M. A. Alkan, U. Çeken, T. Öztürk, and A. Sezen, "Microtremor array measurements for shallow S-wave profiles at strongmotion stations in Hatay and Kahramanmaras Provinces, Southern Turkey," Bulletin of the Seismological Society of America, vol. 107, no. 1, pp. 445-455, 2016. doi: https://doi.org/10.1785/ 0120160218
[30] S. V. Aditya, M. Duraiselvam, K. Parthiban, and V. Bagade, "Laser surface texturing of nickel superalloy to improve adhesion bond strength of thermal barrier coating," International Journal of Applied and Physical Sciences, vol. 3, no. 3, pp. 85-92, 2017. doi: https://doi.org/10.20469/ijaps.3.50005-3

[31] T. S. Irmak and M. F. Özer, "23rd February, 1990 cyprus earthquake welding mechanism," Earthquake Research Bulletin, vol. 80, pp. 109-134, 1999.

[32] N. Febryanti and D. Gunawan, "PAPR reduction in OFDM system with wavelet transformation and partial transmit sequence technique," Journal of Advances in Technology and Engineering Studies, vol. 3, no. 1, pp. 1-5, 2017. doi: https://doi.org/10. 20474/jater-3.1.1

[33] C. Park, R. Miller, and J. Xia, "Multi-channel analysis of surface waves (MASW)," Geophysics, vol. 64, no. 3, pp. 800-808, 1999. doi: https://doi.org/10. $1190 / 1.1444590$

[34] J. Xia, R. D. Miller, and C. B. Park, "Estimation of near-surface shear-wave velocity by inversion of rayleigh waves," Geophysics, vol. 64, no. 3, pp. 691-700, 1999. doi: https://doi.org/10.1190/ 1.1444578 